\begin{tabular}{|l|l|}
$\begin{array}{l}\text { Postprint } \\
\text { Version }\end{array}$ & 1.0 \\
\hline Journal website & $\underline{\text { http://www.sciencedirect.com/science/article/pii/S0277953613005236 }}$ \\
\hline Pubmed link & $\underline{\text { http://www.ncbi.nlm.nih.gov/pubmed/24355465 }}$ \\
\hline DOI & $10.1016 /$ j.socscimed.2013.09.017 \\
\hline
\end{tabular}

This is a NIVEL certified Post Print, more info at http://www.nivel.eu

\title{
Political, cultural and economic foundations of primary care in Europe
}

\author{
DiONNE S. KRINGOS ${ }^{\text {A, B }}$, WIENKE G.W. BOERMA ${ }^{\mathrm{A}}$, JOUKE VAN DER ZEE ${ }^{\mathrm{A}, \mathrm{C}}$, , PETER P. \\ GROENEWEGEN $^{\mathrm{A}, \mathrm{D}}$, \\ ${ }^{a}$ NIVEL-Netherlands Institute for Health Services Research, Otterstraat 114-118, 3513 CR \\ Utrecht, the Netherlands \\ ${ }^{\mathrm{b}}$ Department of Social Medicine, Academic Medical Centre (AMC), University of Amsterdam, \\ Meibergdreef 9, 1105 AZ Amsterdam, The Netherlands \\ ' Department of International Health, Maastricht University, P.O. Box 616, 6200 MD \\ Maastricht, The Netherlands \\ ${ }^{\mathrm{d}}$ Department of Human Geography, Department of Sociology, University of Utrecht, P.O. \\ Box 80140, 3508 TC Utrecht, The Netherlands
}

\begin{abstract}
This article explores various contributing factors to explain differences in the strength of the primary care (PC) structure and services delivery across Europe. Data on the strength of primary care in 31 European countries in 2009/10 were used. The results showed that the national political agenda, economy, prevailing values, and type of healthcare system are all important factors that influence the development of strong PC. Wealthier countries are associated with a weaker PC structure and lower PC accessibility, while Eastern European countries seemed to have used their growth in national income to strengthen the accessibility and continuity of PC. Countries governed by left-wing governments are associated with a stronger PC structure, accessibility and coordination of PC. Countries with a social-security based system are associated with a lower accessibility and continuity of PC; the opposite is true for transitional systems. Cultural values seemed to affect all aspects of PC. It can be concluded that strengthening PC means mobilising multiple leverage points, policy options, and political will in line with prevailing values in a country.
\end{abstract}

\section{INTRODUCTION}

\section{Measuring and managing the strength of primary care}

Primary care (PC) is the first level of professional care where people present their health problems and where the majority of the population's curative and preventive 
Kringos, D.S., Boerma, W.G.W., Zee, J. van der, Groenewegen, P.P. Political, cultural and economic foundations of primary care in Europe. Social Science \& Medicine: 2013, 99(dec), 9-17)

health needs are satisfied (Kringos, Boerma, Hutchinson, Van der Zee, \& Groenewegen, 2010). The strength of a country's primary care system is determined by the degree of development of a combination of core primary care functions (e.g. accessibility and continuity of PC) in the context of its system (Kringos et al., 2010b, Levesque et al., 2012 and Starfield, 1992). Suboptimal PC service delivery threatens the achievement of healthcare system goals (Starfield, Shi, \& Macinko, 2005). It is unknown why PC in some countries is more accessible, provides better quality of care, and offers a broader scope of healthcare services compared to others. Strong $\mathrm{PC}$ requires continuous efforts to maintain, restore or strengthen its functions to deliver high quality professional care. It is a continuous PC management process that most likely requires resources, political will, public engagement and a facilitating healthcare system context (Groenewegen \& Delnoij, 2003). Sidel and Sidel (1977) argued that PC is a reflection of a society's economic, social political, cultural history and the general structure of the healthcare system. Empirical evidence for this statement is however lacking because measuring and monitoring PC development is not common practice, and existing PC instruments are often limited in their measurement domains (e.g. Bower et al., 2003 and Tovey and Adams, 2001), geographical scope (e.g. Kringos, Boerma, Spaan, \& Pellny, 2008) or use of indicators (e.g. Starfield et al., 2005). However, this situation recently improved with the availability of the comparative data set on the strength of PC of 31 European countries in 2009/10 (see www.phameu.eu) resulting from the EU-funded PHAMEU project. Data are available on the key PC functions measuring the existing PC structures (e.g. PC governance, funding and workforce issues) and key aspects of primary care services delivery of countries (Kringos, Boerma, Bourgueil et al., 2010). The results showed variation in the overall strength of PC across 31 European countries in 2009/10 (see Fig. 1).

This article aims to explore the relationship between the strength of PC and a country's economic development, political orientation, type of healthcare system, and prevailing values, to identify the conditions favouring the development of strong PC. A number of hypotheses will be tested, as discussed in the following sections.

\section{Economic development}

The state of a country's economy not only determines the extent to which resources can be generated for its healthcare system, but also policy options to structure and organise the healthcare system. PC provides a more affordable solution to common health problems as opposed to specialist care (Delnoij, van Merode, Paulus, \& Groenewegen, 2000; Kruk, Porignon, Rockers, \& Van Lerberghe, 2010). However, high-income countries can afford to base their healthcare system more on hospital care than on PC (World Health Organization, 2008). Despite inefficiencies (Pelone et al., 2012), public satisfaction is often higher in healthcare systems offering directly accessible specialist care (Kroneman, Maarse, \& Van der Zee, 2006). In such systems, cost sharing arrangements are commonly introduced to control patients' demands, reducing PC access (Ros, Groenewegen, \& Delnoij, 2000).

The following hypothesis will therefore be tested: 
Kringos, D.S., Boerma, W.G.W., Zee, J. van der, Groenewegen, P.P. Political, cultural and economic foundations of primary care in Europe. Social Science \& Medicine: 2013, 99(dec), 9-17)

Hypothesis 1. Countries with a higher (growth in) economic development have weaker PC because they can afford to base their healthcare system more on hospital care than on PC, which is often accompanied by a higher public satisfaction.

\section{Role of politics}

Countries with a predominantly left-wing (socialist or social-democratic) government aim to achieve universalism and equity, provide a redistributive social security system and generous benefits, and have a strong interventionist state. The opposite is true for predominantly right-wing (liberal) governed countries (Bambra, 2006, Eikemo et al., 2008, Esping-Andersen, 1990 and Navarro et al., 2003).

Values commonly lead to political representation in a country. Previous research has shown that the political composition of a country's government is related to healthcare system policy priorities (Boerma, 1989, Groenewegen, 1994 and Tenbensel et al., 2012). Left-wing governments are associated with less regional disparities in healthcare supply; and more interference in hospital planning (Bennema-Broos et al., 2001 and Westert and Groenewegen, 1999), likely due to their policy priorities (Tenbensel et al., 2012). PC can be seen as a health equity producing policy. Although the empirical evidence is still inconclusive, there are indications that access for people with low socioeconomic status is better in healthcare systems with strong PC, contributing to equity in health (Starfield, 2006 and Starfield, 2011).

The following hypothesis will therefore be tested:

Hypothesis 2. Countries that for a longer period have been governed by left-wing parties have stronger PC because strong PC seems to fit with the underlying principles and policy priorities of left-wing parties.

\section{Structure of healthcare systems}

Following the fall of communism in Eastern Europe, the healthcare systems in this region were mostly in transition from their Soviet Union's system to social securitybased systems (SHI). SHI and national health service (NHS) systems differ in terms of the role of government, financing, healthcare providers, and users of care. Stateregulated healthcare systems (NHS systems) can relatively easily implement government initiated reforms (particularly addressing health outcomes and inequalities), compared to SHI countries with a relatively weak power base of the government, as policy implementation depends on the cooperation of insurers and providers (Groenewegen, 1994 and Schmid et al., 2010; Tenbensel et al., 2012; Van der Zee \& Kroneman, 2007). Strong PC - as a lever to achieve these system goals is more likely to be part of the policy agenda of NHS systems (Tenbensel et al., 2012).

The following hypothesis will therefore be tested:

Hypothesis 3. Countries with NHS systems (compared to SHI systems or healthcare systems in transition) have stronger PC due to their hierarchical structure which may facilitate primary care reforms. 


\section{Values}

Several studies have shown that differences in society's values may explain variation in healthcare policy priorities, services delivery, healthcare utilisation and outcomes (e.g. Arrindell et al., 2003, Deschepper et al., 2008, Erumban and De Jong, 2006, Ros et al., 2000 and Saltman and Figueras, 1997). Value systems affect policy makers' healthcare system priorities (e.g. investing more in high technology based specialist care versus PC), medical professionals' behaviour towards patients (e.g. wait-and-see approach versus high intervention rates), and patients' healthcare use (e.g. preference for informal family-based care versus professional medical care) and expectations (e.g. co-decision making versus the doctor-knows-best-belief). The following hypotheses will therefore be tested.

Countries where people value:

- high government involvement (versus individual responsibility) in providing welfare have relatively strong PC because this facilitates the acceptability of pro-PC reforms (hypothesis 4).

- a tight family-orientation have relatively weak PC because people prefer to rely on informal care as opposed to formal care, reducing the urgency for policy makers to continuously invest in strong PC (hypothesis 5).

- the use of science and technology to improve their health have a relatively weak PC because people prioritise the supply and use of specialised medicine over general medicine (hypothesis 6).

\section{METHODS}

\section{Countries}

Our database covers 27 EU Member States, Switzerland, Turkey, Norway, and Iceland.

As the creation of strong PC is a long-term process, there is likely to be a time-lag between changes in political, economic, values or healthcare system contexts to have an effect on PC strength. We therefore take into account the strength of PC, and all relevant external factors for the period 1993-2010, which marks the period when most Central-Eastern European countries had gained independence and started major healthcare system reforms.

Table 1 provides an overview of all variables, the sources used, and coverage of countries and years.

\section{Dependent variables}

The following five dependent variables for PC strength will be used, based on the PHAMEU project (Kringos, Boerma, Bourgueil et al., 2010) and earlier primary care studies (e.g. the work of Barbara Starfield (1992)):

1. Structure of PC;

2. Accessibility of PC;

3. Continuity of PC;

4. Coordination of PC; 
5. Comprehensiveness of PC.

Variable 1 indicates the strength of PC structures of countries. It reflects the existence of PC policies and regulations, the availability of financial resources for PC and coverage for PC services, and the development of the PC workforce. Since the underlying aspects of PC structure are positively correlated with each other (Spearman's correlation values were between 0.49 and 0.55 ) they can be summarized by one variable indicating the overall strength of a country's PC structure. The PC process functions (variables 2-5) are not strongly correlated with each other and therefore four separate dependent variables will be used (Kringos, 2012). The accessibility of primary care was measured by the national and geographic supply of primary care services, the way access is organized in primary care practices, and the affordability and acceptability of primary care services as perceived by patients.

Continuity of primary care was measured by conditions for an enduring doctorpatient relationship, provisions to ensure informational continuity of care, and elements of the quality of the doctor-patient relationship. Coordination of primary care was measured by the existence of a gatekeeping system, the skill-mix of primary care providers, the collaboration within primary care and with secondary care providers, and the integration of certain public health functions in primary care. The comprehensiveness of primary care was measured by the breadth of services offered to patients at primary care level. See Kringos, Boerma, Bourgueil et al. (2010) for the list of indicators from which the dependent variables are constructed. All five dependent variables are continuous, ranging from 0 (relatively weak PC) to 3 (relatively strong PC). The calculation of values has been explained in detail elsewhere (Kringos, 2012).

\section{Independent variables}

Seven independent variables were used to test the hypotheses. The wealth of a country is measured by (WHO, 2011):

1. Gross domestic product (real) in PPP USD per capita in 1993;

2. Development of gross domestic product (real) in PPP USD per capita in the period 1993-2009.

The political composition of a country's government is measured by (Armingeon et al., 2010):

3. The weighted number of years social-democrats or socialists were in power in the period 1993-2008.

Given the time it takes to develop and implement health policy agenda's, the duration of left-wing needs to be taken into account. To account for the different influence of purely left-wing (social-democrats or socialists) governments versus coalition governments (with centre and/or right wing parties), years were counted as $1,0.75$, $0.5,0.25$, or 0 respectively when left wing parties held $100 \%$, >66.6\%, 33.3-66.6\%, 
$<33.3 \%, 0 \%$ of the total cabinet posts, weighted by the number of days the government was in office in a given year.

The structure of a healthcare system is identified by the three major types (European Observatory on Health Systems and Policies, 2011):

4. National health service system (NHS; yes $=1 /$ no $=0$ ), social-security based system $(\mathrm{SHI}$; yes $=1 / \mathrm{no}=0)$, transitional system $($ TRANS; yes $=1 /$ no $=0$ )

The prevailing values of the inhabitants of country are measured by:

5. \% of population that agree with the statement "The government should take more responsibility to ensure that everyone is provided for" (World Values Survey Association, 2009).

6. \% of population preferring children to take care of an elderly father or mother who lives alone and can no longer manage to live without regular help because of her or his physical or mental health condition, instead of other solutions (incl. professional care) (TNS Opinion \& Social \& TNS, 2007).

7. \% of population that agree with the statement "Science and technology are making our lives healthier" (TNS Opinion \& Social, 2010).

In addition, as a possible confounding factor to all hypotheses, the strength of PC in 1993 was measured by:

8. The involvement of general practitioners (GPs) in first contact care for various health problems (of children and women, psychosocial problems and acute health problems) in 1993 (Boerma, Van der Zee, \& Fleming, 1997).

It is a continuous variable ranging from 1 (low involvement) to 4 (high involvement), with a high total scale reliability (Cronbach's $\alpha=0.94)$.

\section{Statistical analyses}

Three types of multivariable regression analyses were performed, each including one dependent (PC) variable and only two independent variables. The analysis was performed for all five dependent PC variables in combination with all independent variables. All simple linear regression analyses were corrected for historical difference in the PC strength of countries (model I); Gross Domestic Product (real) in PPP USD per capita in 1993 (model II; see Appendix A for the correlation); and healthcare systems in transition (model III).

An association was termed significant if $p<0.05$ or $<0.1$. The scatter plots of all variables were examined on relationships with healthcare system type. SPSS/PASW Statistics 18.0 was used.

\section{RESULTS}

\section{Wealth and PC strength}


Kringos, D.S., Boerma, W.G.W., Zee, J. van der, Groenewegen, P.P. Political, cultural and economic foundations of primary care in Europe. Social Science \& Medicine: 2013, 99(dec), 9-17)

The simple regression analyses show no significant linear association between national wealth and PC structure or any aspects of the PC services delivery process (see Table 2). The results of multivariable model I show that after correcting for the strength of PC of countries in 1993, wealthier countries were associated with a significantly weaker PC structure and lower accessibility of PC. Multivariable model III shows that the national income for transitional countries has a significantly positive relationship with the continuity of PC (see Table 2).

The growth in wealth only showed a significant linear association with the accessibility of PC (see Table 2). In transitional countries, the growth in national income is associated with a higher accessibility of PC; whereas this is associated with a lower accessibility of PC in SHI countries. Multivariable models I and II show no significant association between GDP growth and PC structure or any aspects of PC services delivery, after correcting for the strength of PC of countries in 1993 or the absolute level of GDP per capita in 1993.

\section{Government composition and PC strength}

Having a left-wing government has a significantly positive association with PC structure, and accessibility and coordination of PC (see Table 2). After correcting for differences among countries in GDP and the strength of PC in 1993, these associations remain, being strongest with PC structure. Countries with a NHS or SHI system with left-wing governments were associated with having a stronger PC structure, and a higher accessibility and coordination of PC. This was not the case for transitional countries, separately.

\section{Healthcare system type and PC strength}

Countries with a SHI system were associated with a lower accessibility of PC, also after correcting for differences in the strength of PC in 1993 (see Table 2). When correcting for the differences in GDP per capita across countries, the relationship between SHI systems and accessibility of PC is much weaker, and no longer significant.

Transitional healthcare systems were associated with a higher accessibility and better continuity of PC compared to other systems, after correcting for differences in the strength of PC in 1993. Having a SHI system has a negative association with continuity of PC, when taking into account differences in wealth across countries. The structure, accessibility, coordination and comprehensiveness of PC show no association with healthcare system type.

\section{Cultural values and PC strength}

Countries where people value a stronger involvement of the government to ensure that everyone is provided for, were associated with a higher accessibility of PC, after correcting for PC strength in 1993 (see Table 2). These countries were also associated with a better continuity of PC, when taking into account national wealth. However, in terms of coordination and comprehensiveness of care, the relationship works in the opposite direction: countries where people value more government involvement were associated with a weaker coordination of PC and a lower comprehensiveness of PC services, when taking into account national wealth. Particularly, NHS and SHI countries have a significantly negative relationship 
Kringos, D.S., Boerma, W.G.W., Zee, J. van der, Groenewegen, P.P. Political, cultural and economic foundations of primary care in Europe. Social Science \& Medicine: 2013, 99(dec), 9-17)

between desired government involvement and coordination and comprehensiveness of PC. This is not the case for transitional countries.

Countries where people value ill parents being taken care of by their children, were associated with a significantly weaker PC structure and coordination of PC, and a smaller scope of PC services provision (see Table 2). When the PC strength 1993 is taken into account, this relationship holds only for the comprehensiveness of PC. When only correcting for national wealth, this relationship remains valid for both PC structure and the coordination and comprehensiveness of PC (see Table 2).

Particularly in transitional healthcare systems family values are strong (see Table 1), and are positively associated with the accessibility and continuity of PC (see Table 2). NHS and SHI countries have instead, a significantly negative relationship between children preferring to care for ill parents and PC structure and coordination of PC.

Countries where people value the use of science and technology to improve their health were associated with more comprehensive PC services delivery. This was particularly true among NHS and SHI countries. Even after correcting for PC strength 1993 or wealth, this association remained (see Table 2). However, the accessibility of PC showed a different association: countries where people valued science and technology more had a lower accessibility of PC after correcting for PC strength in 1993. Overall, people in countries with a healthcare system in transition valued the use of science and technology to improve their health the least, but this had no significant relationship with PC structure or any aspect of the PC services delivery process.

\section{DISCUSSION}

\section{Mixed impact of wealth on PC strength}

Hypothesis 1 was to a great extent supported by the findings: wealthier countries were found to transition to weaker PC structures and accessibility over the period being examined, although coming off a relatively strong PC base, probably because they could afford to gear their governance, healthcare workforce, and funding arrangements towards expensive specialised care to satisfy public expectations. Although this occurred both at the expense of the structure of PC and its accessibility, the growth in GDP only was negatively associated with accessibility of PC among NHS and SHI countries. This might be the result of the introduction of copayments limiting access. In transitional countries wealth seemed to have boosted both PC accessibility (e.g. by increasing the availability of PC services), and the continuity of PC (e.g. by introducing personal physicians). PC was relatively weak in the early nineties, and every extra investment therefore had a relatively big impact. The (growth in) national income showed no association with the coordination or comprehensiveness of PC, possibly because coordination of PC requires the streamlining of processes, skill-mix and teamwork which need other types of incentives to facilitate this, and all healthcare systems should provide at least a minimum scope of basic care services in PC regardless their wealth.

\section{Left-wing governments foster strong PC}


Kringos, D.S., Boerma, W.G.W., Zee, J. van der, Groenewegen, P.P. Political, cultural and economic foundations of primary care in Europe. Social Science \& Medicine: 2013, 99(dec), 9-17)

The most evident impact on PC strength was the government composition of countries, supporting hypothesis 2 . The political agenda of left-wing parties seems to impact the structure of PC by implementing PC supportive policies, ensuring financial coverage for all inhabitants, and investing in the development of the PC workforce. At process level, left-wing parties probably affect PC access by e.g. reducing financial barriers to care and warranting an equal geographical distribution of PC services. Coordination of care is most likely affected by streamlining care processes around patients and introducing gatekeeping systems to limit possible over-consumption of care. Perhaps continuity of PC is not influenced by a country's government composition because it is more related to the organisation of care at practice level and traditions of the medical professions (e.g. recording and communicating medical information) not directly related to political principles. Perhaps the comprehensiveness of PC is not affected by government composition because the tasks and duties of PC professionals are often laid down in regulations; which is not easily changed by political parties.

\section{The relevance of the type of healthcare system}

Hypothesis 3 was not fully supported by our findings. Interestingly, different types of healthcare systems have a different relationship with PC strength. SHI countries were associated with a weaker accessibility and continuity of PC, perhaps due to a lack of gatekeeping system and use of co-payments to control healthcare use, both affecting continuity (e.g. absence of patient lists) and access (e.g. affordability of care) to PC. Transitional countries were associated with a higher accessibility and better continuity of PC, and seemed to have used the growth of national income to the benefit of the strength of PC, unlike NHS and SHI countries. This is likely the result of a difference in history, coming from a highly centralized system influenced by communism, with a strong focus on specialists and hospital care, and PC provided by gynaecologists, paediatricians and therapists with a low professional status. This created a sense of urgency among these countries to implement major reforms to strengthen the overall healthcare system, which some countries implemented sooner and more successfully than others.

\section{Values affect all aspects of PC strength}

Together, the cultural values affect all PC dimensions. It is the only independent variable that is significantly associated with the comprehensiveness of PC services offered (all three values mattered).

Hypothesis 4 was only partly supported by the findings. Countries where people wanted more government involvement were associated with a stronger accessibility and continuity of PC, but a weaker coordination and comprehensiveness of care. Perhaps governments were under pressure to act upon prevailing values, and therefore prioritised investments in access and continuity of PC because these are often more directly visible to the public, neglecting other less visible aspects of the services delivery process, such as coordination and comprehensiveness of PC. This could have been a strategy to satisfy the general public and limit expenditures. Also hypothesis 5 was only partly supported by the findings. It is true that more family oriented countries were associated with a weaker PC structure, less coordination of PC, and a smaller scope of PC services provision. This may be the 
Kringos, D.S., Boerma, W.G.W., Zee, J. van der, Groenewegen, P.P. Political, cultural and economic foundations of primary care in Europe. Social Science \& Medicine: 2013, 99(dec), 9-17)

result of a lack of political need to strengthen these elements of PC, since the population prefers informal care over the use of professional care, but it could also be the case that informal care networks are all people have when PC is weak, so they come to accept, value and normalise them. However, transitional countries which have a strong family orientation were associated with higher PC access and better continuity of PC.

Hypothesis 6 was only true with regard to PC access. Countries with a strong science and technology focus were associated with a lower accessibility of PC, probably because more human resources are made available for secondary care at the expense of PC. Apparently this value does not affect PC policies, education systems or coverage schemes for PC. More so, it seemed to have increased the comprehensiveness of PC, probably because it has made more medical technical procedures and applications possible in PC.

\section{Strength and limitation}

This article was based on a rich, comparable, up-to-date data set on PC in 31 European countries, providing a unique opportunity to study the external factors that influence the strength of PC, which have never been studied on such a scale before. This was a highly relevant analysis given the recently proven impact that strong primary care has on better population health, fewer health disparities, and lower rates of unnecessary hospitalizations (Kringos, Boerma, Van der Zee, \& Groenewegen, 2013). It should be noted however that all independent variables included in this paper are part of complex patterns of relationships (e.g. values affect government representation and characteristics of health systems often form fixed combinations that are historically fixed and therefore difficult to separate), which are challenging to analyse statistically. This may explain the relatively low R2 in some of the regression analyses. There is need for interaction analyses, and the identification of additional factors that may be of influence on PC. However, the possibility for this is currently very limited, among others due to the limited number of countries included in international comparative papers. From a methodological point of view 31 countries is still very limited, and it would be desirable to add more OECD countries.

\section{CONCLUSION}

Countries differ in their PC strength due to differences in wealth, political composition of their government, prevailing values, and type of healthcare system. This implies that progress to stronger PC means mobilising multiple leverage points, policy options, and political will in line with prevailing values in a country.

\section{ACKNOWLEDGEMENTS}

The authors would like to thank all PHAMEU project partners for their important contributions made, particularly in collecting the primary care data in all countries: Y. Bourgueil, T. Cartier (France); T. Dedeu (Spain); T. Hasvold (Norway); A. Hutchinson (United Kingdom); M. Lember (Estonia); M. Oleszczyk (Poland); D. Rotar Pavlič, I. Švab (Slovenia); P. Tedeschi (Italy); S. Wilm (Germany); A. Wilson (United Kingdom); A. Windak (Poland). 
Kringos, D.S., Boerma, W.G.W., Zee, J. van der, Groenewegen, P.P. Political, cultural and economic foundations of primary care in Europe. Social Science \& Medicine: 2013, 99(dec), 9-17)

The authors are grateful to the PHAMEU project contributions made by D. Aarendonk (European Forum for Primary Care), H. Abholz (Germany), B. Bolibar (Spain), B. Christensen (Norway), and E. Frigola (Spain).

Special thanks go out to all PHAMEU national coordinators contributing to the primary care data collection: M. Sprenger (Austria); L. Ryssaert (Belgium); P. Salchev (Bulgaria); G. Samoutis (Cyprus); B. Seifert (Czech Republic); Johan Sahl Andersen (Denmark); K. Winell (Finland); M. Redaèlli, D. Simic (Germany); C. Lionis, A. Saridaki (Greece); P. Vajer, I. Rurik (Hungary); S. Veide, K. Põlluste (Latvia); V. Kasiulevičius (Lithuania); M. Aubart, J. Leners, R. Stein (Luxembourg); J. K. Soler, M. R. Sammut (Malta); Thomas Hasvold, Knut Gaute Vardenær (Norway); C. Fonseca, L. Pisco, A. Gouveia (Portugal); R. Miftode, A. Balan, Z. Farkas Pall (Romania); E. Jurgova (Slovakia); R. Brinovec Pribaković (Slovenia); J. Gené, C. Pareja, C.Violan (Spain); Göran Carlson, Ingvar Ovhed (Sweden); N. Senn, J. Cornuz (Switzerland); M. Akman (Turkey).

\section{REFERENCES}

M. Akman, Personal communication.(2011) 15-11-2011

K. Armingeon, R. Careja, S. Engler, P. Potolidis, M. Gerber, P. Leimgruber Comparative political data set III 1990-2008 Institute of Political Science, University of Berne, Berne (2010)

W.A. Arrindell, A. Steptoe, J. Wardle Higher levels of state depression in masculine than in feminine nations Behaviour Research and Therapy, 41 (2003), pp. 809-817

Health status and the worlds of welfare Social Policy and Society, 5 (2006), pp. 53-62

M. Bennema-Broos, P.P. Groenewegen, G.P. Westert Social democratic government and spatial distribution of health care facilities European Journal of Public Health, 11 (2) (2001), pp. 160-165

W.G.W. Boerma Local housing scheme and political preference as conditions for the results of a health centre-stimulating policy in the Netherlands Health Policy, 13 (1989), pp. 225237

W.G.W. Boerma, J. Van der Zee, D.M. Fleming Service profiles of general practitioners in Europe British Journal of General Practice, 47 (1997), pp. 481-486

P. Bower, S. Campbell, C. Bojke, B. Sibbald Team structure, team climate and the quality of care in primary care: an observational study Quality \& Safety in Health Care, 12 (4) (2003), pp. 273-279

D. Delnoij, G. van Merode, A. Paulus, P. Groenewegen Does general practitioner gatekeeping curb health care expenditure? Journal of Health Services Research \& Policy, 5 (1) (2000) 22-6

R. Deschepper, L. Grigoryan, C. Stalsby Lundborg, G. Hofstede, J. Cohen, G. Van der Kelen et al. Are cultural dimensions relevant for explaining cross-national differences in antibiotic use in Europe? BMC Health Services Research, 8 (2008), pp. 123-132

T.A. Eikemo, M. Huisman, C. Bambra, A. Kunst Health inequalities according to educational level in different welfare regimes: a comparison of 23 European countries Sociology of Health and Illness, 30 (4) (2008), pp. 565-582

A.A. Erumban, S.B. De Jong Cross-country differences in ICT adoption: a consequence of Culture? Journal of World Business, 41 (2006), pp. 302-314 
Kringos, D.S., Boerma, W.G.W., Zee, J. van der, Groenewegen, P.P. Political, cultural and economic foundations of primary care in Europe. Social Science \& Medicine: 2013, 99(dec), 9-17

G. Esping-Andersen The three worlds of welfare capitalism Polity, London (1990) European Observatory on Health Systems and Policies Health system profiles (HITs) publications (2011)

P.P. Groenewegen The shadow of the future: Institutional change in health care Health Affairs, 13 (5) (1994), pp. 137-148

P.P. Groenewegen, D.M.J. Delnoij De Nederlandse gezondheidszorg in Europees perspectief C.W. Aakster, J.W. Groothof (Eds.), Medische sociologie, Wolters-Noordhof, Groningen/Houten (2003), pp. 155-172

D.S. Kringos, W.G.W. Boerma, J. Van der Zee, P.P. Groenewegen Europe's strong primary care systems are linked to better population health, but also to higher health spending Health Affairs, 32 (4) (2013), pp. 686-694

D.S. Kringos The strength of primary care in Europe Thesis NIVEL/Utrecht University (2012)

D.S. Kringos, W.G.W. Boerma, Y. Bourgueil, T. Cartier, T. Hasvold, A. Hutchinson et al. The European Primary Care Monitor: structure, process and outcome indicators BMC Family Practice, 11 (2010), pp. 81-89

D.S. Kringos, W.G.W. Boerma, A. Hutchinson, J. Van der Zee, P.P. Groenewegen The breadth of primary care: a systematic literature review of its core dimensions BMC Health Services Research, 10 (1) (2010), pp. 65-78

D.S. Kringos, W.G.W. Boerma, E. Spaan, M. Pellny Primary care evaluation in the Russian Federation WHO, Copenhagen (2008)

M.W. Kroneman, J.A.M. Maarse, J. Van der Zee Direct access in primary care and patient satisfaction: a European study Health Policy, 76 (1) (2006), pp. 72-79

M.E. Kruk, D. Porignon, P.C. Rockers, W. Van Lerberghe The contribution of primary care to health and health systems in low- and middle-income countries: a critical review of major primary care initiatives Social Science \& Medicine, 70 (2010), pp. 904-911

J. Levesque, J. Haggerty, G. Beninguisse, F. Burge, D. Gass, M. Beaulieu et al. Mapping the coverage of attributes in validated instruments that evaluate primary health care from the patient perspective BMC Family Practice, 13 (2012), p. 20

V. Navarro, C. Borrell, J. Benach, C. Muntaner, A. Quiroga, M. Rodriquez-Sanz et al. The importance of the political and the social in explaining mortality differentials among the countries of the OECD, 1950-1998 International Journal of Health Services Research, 33 (2003), pp. 419-494

F. Pelone, D.S. Kringos, A. Romaniello, L. Valerio, A. Lazzari, W. Ricciardi et al. The measurement of relative efficiency of general practice and the implications for policy makers Health Policy (2012) http://dx.doi.org.proxy.library.uu.nl/10.1016/j.healthpol.2012.05.005

C.C. Ros, P.P. Groenewegen, D.M.J. Delnoij All rights reserved, or can we just copy? Cost sharing arrangements and characteristics of health care systems Health Policy, 52 (2000), pp. 1-13

R. Saltman, J. Figueras European health care reform. Analysis of current strategies WHO Regional Publications, Geneva (1997) A. Schmid, M. Cacae, R. Götze, H. Rothgang Explaining health care system change: problem pressure and the emergence of "Hybrid" health care systems J Health Polit Policy Law, 35 (4) (2010)

P.A. Sciortino Service profile of Maltese general practitioners. A provider survey of the general practice component of the Maltese Health Care system University of Malta. (2002)

V.W. Sidel, R. Sidel Primary health care in relation to socio-political structure Social Science \& Medicine, 11 (1977), pp. 415-419

B. Starfield Primary care: Concept, evaluation, and policy Oxford University Press, Inc, New York (1992)

B. Starfield State of the art in research on equity in health Journal of Health Politics, Policy and Law, 31 (2006), pp. 11-32 
Kringos, D.S., Boerma, W.G.W., Zee, J. van der, Groenewegen, P.P. Political, cultural and economic foundations of primary care in Europe. Social Science \& Medicine: 2013, 99(dec), 9-17

B. Starfield Politics, primary healthcare and health: was Virchow right? Journal of Epidemiology and Community Health, 65 (8) (2011), pp. 653-655

B. Starfield, L. Shi, J. Macinko Contribution of primary care to health system and health Milbank Q, 83 (2005), pp. 457-502

T. Tenbensel, S. Eagle, T. Ashton Comparing health policy agendas across eleven high income countries: islands of difference in a sea of similarity Health Policy (2012) http://dx.doi.org.proxy.library.uu.nl/10.1016/j.healthpol.2012.04.011

TNS Opinion \& Social Special eurobarometer 340 science and technology European Commission, Brussels (2010)

TNS Opinion \& Social, TNS Special eurobarometer 283 health and long-term care in the European Union European Commission, Brussels (2007)

P. Tovey, J. Adams Primary care as intersecting social worlds Social Science \& Medicine, 52 (2001), pp. 695-706

J. Van der Zee, M.W. Kroneman Bismarck or Beveridge: a beauty contest between dinosaurs

BMC Health Services Research, 7 (2007), pp. 94-105

G.P. Westert, P.P. Groenewegen Regional disparities in health care supply in eleven

European countries: do politics matter? Health Policy, 47 (2) (1999), pp. 169-182

WHO European health for all database World Health Organization (2011)

WHO The World Health Report 2008: Primary health care now more than ever

WHO, Geneva (2008) World Values Survey Association World values survey 1981-2008

Official Aggregate v.20090901 ASEP/JDS, Madrid (2009) 
Kringos, D.S., Boerma, W.G.W., Zee, J. van der, Groenewegen, P.P. Political, cultural and economic foundations of primary care in Europe. Social Science \& Medicine: 2013, 99(dec), 9-17)

\section{TABLES AND FIGURES}

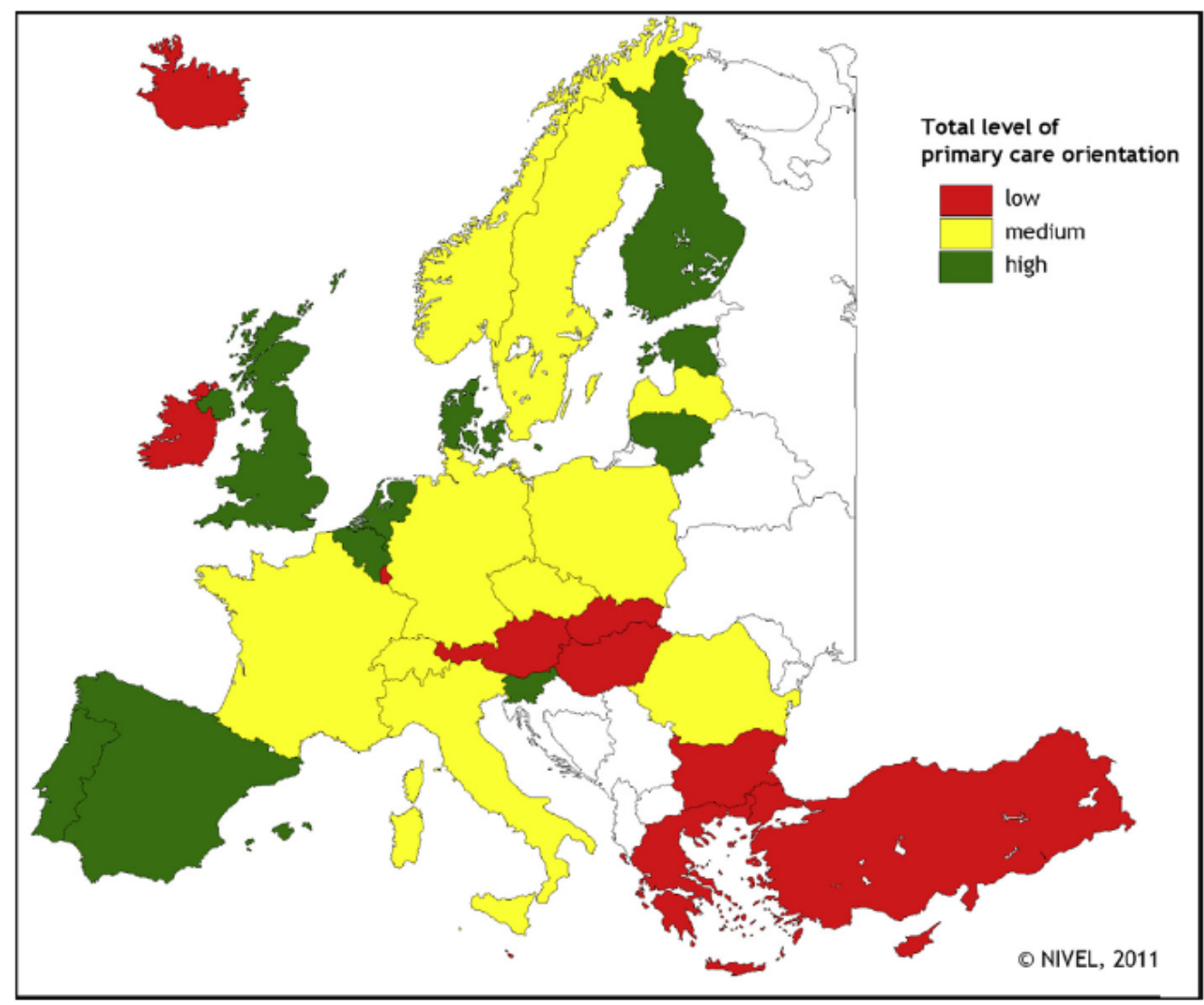

Fig. 1. Variation in primary care strength across Europe. 
Table 1

Overview of variables by country.

\begin{tabular}{|c|c|c|c|c|c|c|c|c|c|c|c|c|c|}
\hline & $\begin{array}{l}\text { PC structure } \\
\text { strengtha }^{2} \\
(2009 / 10)\end{array}$ & $\begin{array}{l}\text { Access: PC } \\
\text { process } \\
\text { strength } \\
(2009 / 10)\end{array}$ & $\begin{array}{l}\text { Continuity } \\
\text { of care: PC } \\
\text { process } \\
\text { strength } \\
(2009 / 10)\end{array}$ & $\begin{array}{l}\text { Coordination } \\
\text { of care: PC } \\
\text { process } \\
\text { strength } \\
(2009 / 10)\end{array}$ & $\begin{array}{l}\text { Comprehen- } \\
\text { siveness: PC } \\
\text { process } \\
\text { strengtha }^{\mathrm{a}} \\
(2009 / 10)\end{array}$ & $\begin{array}{l}\text { GPs' } \\
\text { involvement } \\
\text { first contact } \\
\text { care }^{\mathrm{b}} \text { (1993) }\end{array}$ & $\begin{array}{l}\text { GDP per } \\
\text { capita } \\
\text { (PPP USD) } \\
(1993)\end{array}$ & $\begin{array}{l}\text { \% Growth in } \\
\text { GDP per } \\
\text { capita (PPP } \\
\text { USD) 1993- } \\
2009\end{array}$ & $\begin{array}{l}\text { Yrs left party } \\
\text { government } \\
\text { dominance } \\
1993-2008\end{array}$ & $\begin{array}{l}\text { Type of } \\
\text { healthcare } \\
\text { system (2010) }\end{array}$ & $\begin{array}{l}\text { \% Pop. Agree } \\
\text { govermment } \\
\text { should take } \\
\text { more responsibility } \\
\text { providing welfare } \\
\text { (N;Year) }\end{array}$ & $\begin{array}{l}\text { \% Pop. Prefers } \\
\text { children to } \\
\text { take care of } \\
\text { parent(s) in } \\
\text { case of ill } \\
\text { health }(\mathrm{N}) 2007\end{array}$ & $\begin{array}{l}\text { \% Pop. Agree } \\
\text { healthy impact } \\
\text { science \& } \\
\text { technology } \\
\text { (N)2010 }\end{array}$ \\
\hline Austria & 2.22 & 2.27 & 2.19 & 1.38 & 2.33 & 2.95 & 21563.30 & 80.02 & 4.75 & SHI & na. & $46.06(1003)$ & $64.80(517)$ \\
\hline Belgium & 2.21 & 2.13 & 2.38 & 1.70 & 2.53 & 3.01 & 20482.00 & 77.29 & 7.75 & SHI & n.a & 37.95 (1033) & $57.84(529)$ \\
\hline Bulgaria & 2.14 & 2.15 & 2.33 & 1.44 & 2.54 & 1.74 & 5030.37 & 175.72 & 5.14 & TRANS & $53.24(971 ; 1997)$ & 79.59 (1014) & $44.36(505)$ \\
\hline Cyprus & 1.91 & 2.11 & 2.32 & 1.49 & 2.19 & n.a. & 13683.20 & 125.45 & 4.25 & NHS & $51.58(1043 ; 2006)$ & $65.43(486)$ & $56.80(250)$ \\
\hline Czech Rep. & 2.14 & 2.35 & 2.41 & 1.64 & 2.33 & 2.28 & 10500.20 & 143.62 & 6.25 & TRANS & $55.97(1147 ; 1998)$ & $65.04(1027)$ & $39.12(524)$ \\
\hline Denmark & 2.38 & 2.46 & 2.43 & 1.96 & 2.40 & 3.49 & 20439.60 & 84.55 & 6.25 & NHS & n.a & 21.97 (1006) & $64.23(520)$ \\
\hline Estonia & 2.29 & 2.21 & 2.42 & 1.71 & 2.41 & 2.06 & 5645.03 & 248.86 & 4.75 & TRANS & $63.80(1011 ; 1996)$ & $59.52(1003)$ & $52.86(490)$ \\
\hline Finland & 2.31 & 2.20 & 2.32 & 1.74 & 2.51 & 3.00 & 16868.40 & 109.06 & 6.50 & NHS & $31.49(975 ; 1996)$ & $31.12(1041)$ & $64.62(537)$ \\
\hline France & 2.16 & 2.06 & 2.33 & 1.63 & 2.47 & 3.08 & 18715.10 & 79.93 & 5.25 & SHI & 28.06 (998;2006) & 37.32 (1096) & $63.57(516)$ \\
\hline Germany & 2.20 & 2.25 & 2.38 & 1.38 & 2.34 & 2.82 & 20756.00 & 75.07 & 8.50 & SHI & $46.97(2014 ; 1997)$ & $53.78(1523)$ & 36.02 (769) \\
\hline Greece & 2.10 & 2.08 & 2.25 & 1.96 & 2.17 & 2.47 & 13738.30 & 115.58 & 10.50 & NHS & n.a & $86.26(1012)$ & $46.88(529)$ \\
\hline Hungary & 2.08 & 2.34 & 2.33 & 1.46 & 2.29 & 2.75 & 8066.11 & 151.82 & 9.00 & TRANS & $65.99(638 ; 1998)$ & 70.18 (1006) & $49.52(523)$ \\
\hline Iceland & 1.77 & 2.28 & 2.40 & 1.60 & 2.42 & 3.10 & 21764.60 & 69.06 & 2.00 & NHS & n.a & n.a. & $64.41(236)$ \\
\hline Ireland & 2.20 & 1.96 & 2.38 & 1.57 & 2.36 & 3.48 & 14973.70 & 171.79 & 2.75 & NHS & na & 41.74 (1011) & $65.08(504)$ \\
\hline Italy & 2.33 & 2.27 & 2.31 & 1.73 & 2.13 & 3.08 & 19283.90 & 68.17 & 5.07 & NHS & $44.11(984 ; 2005)$ & 50.89 (1067) & $41.47(516)$ \\
\hline Latvia & 2.14 & 2.15 & 2.38 & 1.65 & 2.41 & 1.96 & 4910.72 & 234.72 & 4.50 & TRANS & $61.41(1192 ; 1996)$ & 70.55 (1012) & $41.77(486)$ \\
\hline Lithuania & 2.27 & 2.29 & 2.30 & 1.98 & 2.56 & 1.71 & 6292.90 & 175.04 & 8.50 & TRANS & $50.90(998 ; 1997)$ & 74.17 (1026) & $46.33(518)$ \\
\hline Luxembourg & 1.90 & 2.03 & 2.31 & 1.63 & 2.42 & 2.63 & 36469.70 & 129.84 & 5.50 & SHI & n.a & $45.28(360)$ & $68.00(250)$ \\
\hline Malta & 2.12 & 2.17 & 2.17 & 1.82 & 2.38 & 2.80 & 13052.30 & 90.11 & 2.00 & NHS & n.a. & $54.34(495)$ & 58.61 (244) \\
\hline Netherlands & 2.50 & 2.38 & 2.26 & 2.20 & 2.32 & 3.67 & 19703.20 & 106.44 & 5.50 & SHI & $36.41(1041 ; 2006)$ & 22.81 (1004) & $54.60(522)$ \\
\hline Norway & 2.27 & 2.25 & 2.36 & 1.56 & 2.55 & 3.28 & 20901.90 & 168.94 & 8.75 & NHS & $29.95(1122 ; 1996)$ & n.a. & $65.34(479)$ \\
\hline Poland & 2.12 & 2.35 & 2.33 & 1.92 & 2.29 & 2.27 & 5795.92 & 226.18 & 7.25 & TRANS & $41.94(1111 ; 1997)$ & 84.38 (1031) & 43.55 (535) \\
\hline Portugal & 2.41 & 2.34 & 2.35 & 1.62 & 2.47 & 3.22 & 12342.70 & 101.90 & 8.75 & NHS & n.a & $57.96(1068)$ & $45.42(513)$ \\
\hline Romania & 2.31 & 2.26 & 2.33 & 1.55 & 2.20 & 2.36 & 4611.19 & 209.64 & 8.75 & TRANS & $47.77(1187 ; 1998)$ & $78.62(1043)$ & $53.28(533)$ \\
\hline Slovak Rep. & 2.02 & 2.27 & 2.39 & 1.39 & 1.98 & n.a. & 7191.46 & 218.18 & 4.50 & TRANS & $68.12(1076 ; 1998)$ & 74.91 (1084) & 40.08 (499) \\
\hline Slovenia & 2.36 & 2.47 & 2.30 & 1.84 & 2.32 & 2.87 & 11168.20 & 142.95 & 8.00 & TRANS & $52.86(997 ; 1995)$ & 45.21 (1033) & $47.72(505)$ \\
\hline Spain & 2.43 & 2.44 & 2.43 & 1.84 & 2.51 & 3.20 & 14652.40 & 119.42 & 8.25 & NHS & $51.38(1162 ; 1995)$ & 57.80 (993) & $62.98(497)$ \\
\hline Sweden & 2.23 & 2.17 & 2.25 & 2.32 & 2.49 & 2.83 & 19642.20 & 90.29 & 12.00 & NHS & $12.85(1004 ; 1996)$ & $14.82(985)$ & 76.83 (492) \\
\hline Switzerland & 2.04 & 2.17 & 2.37 & 1.63 & 2.42 & 2.88 & 25667.10 & 76.19 & 4.00 & SHI & $16.34(1181 ; 1996)$ & n.a. & $60.00(490)$ \\
\hline Turkey & 2.27 & 2.05 & 2.15 & 1.61 & 2.36 & 2.02 & 5072.25 & 169.46 & 4.00 & SHI & $45.93(1868 ; 1996)$ & $81.92(1001)$ & $66.10(472)$ \\
\hline United & 2.52 & 2.40 & 2.37 & 1.88 & 2.52 & 3.51 & 17692.70 & 98.70 & 11.50 & NHS & $27.23(1032 ; 2006)$ & 44.58 (1283) & $61.39(663)$ \\
\hline Kingdom & & & & & & & & & & & & & \\
\hline \multirow[t]{4}{*}{ Source: } & Kringos & Kringos & Kringos & Kringos & Kringos & Boerma & WHO Regional & & Armingeon & European & World Values & TNS Opinion & TNS Opinion \\
\hline & et al., 2012 & et al., 2012 & et al., 2012 & et al., 2012 & et al., 2012 & et al., 1997; & Office for & Regional & et al., 2010; & Observatory & Survey Association, & \& Social \& & \& Social, 2010 \\
\hline & & & & & & $\begin{array}{l}\text { Sciortino, } \\
2002 \text { (for }\end{array}$ & Europe, 2011 & $\begin{array}{l}\text { Office for } \\
\text { Europe, } 2011\end{array}$ & $\begin{array}{l}\text { Akman, } 2011 \\
\text { (for Turkey) }\end{array}$ & $\begin{array}{l}\text { on Health } \\
\text { Systems and }\end{array}$ & 2009 & TNS, 2007 & \\
\hline & & & & & & Malta) & & & & Policies, 2011 & & & \\
\hline
\end{tabular}

a Scale ranges from 1 (low PC orientation) to 3 (high PC orientation).

b Scale ranges from 1 (low involvement) to 4 (high involvement)

$$
\begin{aligned}
& \text { Systems and } \\
& \text { Policies, } 2011
\end{aligned}
$$


Kringos, D.S., Boerma, W.G.W., Zee, J. van der, Groenewegen, P.P. Political, cultural and economic foundations of primary care in Europe. Social Science \& Medicine: 2013, 99(dec), 9-17

Table $\mathbf{2}$

Regression analysis.

\begin{tabular}{|c|c|c|c|c|c|c|c|c|c|c|}
\hline & & \multirow{2}{*}{\multicolumn{4}{|c|}{ Total PC system strength at structure level }} & \multicolumn{5}{|c|}{$\mathrm{PC}$ system strength at process level by dimension } \\
\hline & & & & & & \multicolumn{4}{|l|}{ Access to PC } & \multirow{2}{*}{ 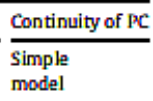 } \\
\hline & & $\begin{array}{l}\text { Simple } \\
\text { model }\end{array}$ & $\begin{array}{l}\text { Multiv. } \\
\text { model I }\end{array}$ & $\begin{array}{l}\text { Multiv. } \\
\text { model II }\end{array}$ & $\begin{array}{l}\text { Multiv. } \\
\text { model III }\end{array}$ & $\begin{array}{l}\text { Simple } \\
\text { model }\end{array}$ & $\begin{array}{l}\text { Multiv. } \\
\text { model I }\end{array}$ & $\begin{array}{l}\text { Multiv. } \\
\text { model II }\end{array}$ & $\begin{array}{l}\text { Multiv. } \\
\text { model III }\end{array}$ & \\
\hline \multirow{2}{*}{$\begin{array}{l}\text { PC system } \\
\text { strength } \\
1993\end{array}$} & $\begin{array}{l}\text { Standard. B } \\
\text { (p-value) }\end{array}$ & $0.327^{*}(0.084)$ & & & $0.539^{\circ}(0.042)$ & $0.258(0.177)$ & & & $0.834^{*}(0.001)$ & $0.169(0.382)$ \\
\hline & $R^{2}(N)$ & $0.107(29)$ & & & $0.154(29)$ & $0.066(29)$ & & & $0.411(29)$ & $0.028(29)$ \\
\hline TRANS $(=0 / 1)$ & $\begin{array}{l}\text { Standard. B } \\
\text { (p-value) }\end{array}$ & & & & $0.303(0.241)$ & & & & $0.823^{*}(0.001)$ & \\
\hline \multirow[t]{2}{*}{$\begin{array}{l}\text { GDP per } \\
\text { caplta } 1993\end{array}$} & $\begin{array}{l}\text { Standard. B } \\
\text { (p-value) }\end{array}$ & $-0.144(0.438)$ & $-0.667^{*}(0.002)$ & & $-0.435(0.109)$ & $-0.129(0.488)$ & $-0.467^{*}(0.046)$ & & $0.125(0.643)$ & $0.032(0.864)$ \\
\hline & $R^{2}(N)$ & $0.021(31)$ & $0.383(29)$ & & $0.095(31)$ & $0.017(31)$ & $0.202(29)$ & & $0.073(31)$ & $0.001(31)$ \\
\hline TRANS $(=0 / 1)$ & $\begin{array}{l}\text { Standard. B } \\
\text { (p-value) }\end{array}$ & & & & $-0.398(0.141)$ & & & & $0.348(0.202)$ & \\
\hline \multirow{2}{*}{$\begin{array}{l}\text { Growth GDP } \\
\text { per caplta } \\
\text { 1993-2009 }\end{array}$} & $\begin{array}{l}\text { Standard B } \\
\text { (p-value) }\end{array}$ & $-0.045(0.812)$ & $0.365(0.123)$ & $-0.301(0.258)$ & $0.043(0.885)$ & $-0.060(0.750)$ & $0.140(0.571)$ & $-0.310(0245)$ & $-0.635(0.021)$ & $0.150(0.421)$ \\
\hline & $R^{2}(N)$ & $0.002(31)$ & $0.186(29)$ & $0.065(31)$ & $0.007(31)$ & $0.004(31)$ & $0.078(29)$ & $0.064(31)$ & $0.230(31)$ & $0.022(31)$ \\
\hline TRANS $(=0 / 1)$ & $\begin{array}{l}\text { Standard. B } \\
\text { (p-value) }\end{array}$ & & & & $-0.114(0.703)$ & & & & $0.746(0.008)$ & \\
\hline \multirow[t]{2}{*}{$\begin{array}{l}\text { Government } \\
\text { composition }\end{array}$} & $\begin{array}{l}\text { Standard. B } \\
\text { (p-value) }\end{array}$ & $0.454^{\circ}(0.010)$ & $0.394^{\circ}(0.027)$ & $0.451^{*}(0.012)$ & $0.460^{\circ}(0.010)$ & $0.352^{*}(0.046)$ & $0.339^{* *}(0.068)$ & $0358^{\circ}(0050)$ & $0.349^{\circ}(0.050)$ & $0.053(0.776)$ \\
\hline & $R^{2}(N)$ & $0.205(31)$ & $0.262(29)$ & $0.224(31)$ & $0.217(31)$ & $0.131(31)$ & $0.181(29)$ & $0.145(31)$ & $0.187(31)$ & $0.003(31)$ \\
\hline TRANS $(=0 / 1)$ & $\begin{array}{l}\text { Standard. B } \\
\text { (p-value) }\end{array}$ & & & & $-0.105(0.535)$ & & & & $0.238(0.173)$ & \\
\hline \multirow{2}{*}{$\begin{array}{l}\text { Healthcare } \\
\text { system } \\
\text { NHS }(=0 / 1)\end{array}$} & $\begin{array}{l}\text { Standard. B } \\
\text { (p-value) }\end{array}$ & $0.127(0.495)$ & $0.009(0.966)$ & $0.173(0.371)$ & & $0.040(0.832)$ & $-0.075(0.742)$ & $0.076(0697)$ & & $0.046(0.804)$ \\
\hline & $R^{2}(N)$ & $0.016(31)$ & $0.107(29)$ & $0.049(31)$ & & $0.002(31)$ & $0.070(29)$ & $0.022(31)$ & & $0.002(31)$ \\
\hline \multirow[t]{2}{*}{$\mathrm{SHI}(=0 / 1)$} & $\begin{array}{l}\text { Standard. B } \\
\text { (p-value) }\end{array}$ & $-0.058(0.758)$ & $-0.170(0.364)$ & $0.021(0.925)$ & & $-0.319^{*}(0.080)$ & $-0.382(0.039)$ & $-0341(0111)$ & & $-0.277(0.132)$ \\
\hline & $R^{2}(N)$ & $0.003(31)$ & $0.135(29)$ & $0.021(31)$ & & $0.102(31)$ & $0.210(29)$ & $0.103(31)$ & & $0.077(31)$ \\
\hline \multirow[t]{2}{*}{ TRANS $(=0 / 1)$} & $\begin{array}{l}\text { Standard. B } \\
\text { (p-value) }\end{array}$ & $-0.081(0.667)$ & $0.303(0.241)$ & $-0398(0.141)$ & & $0.257(0.163)$ & $0.823^{*}(0.001)$ & $0348(0202)$ & & $0.210(0.256)$ \\
\hline & $R^{2}(N)$ & $0.006(31)$ & $0.154(29)$ & $0.095(31)$ & & $0.066(31)$ & $0.411(29)$ & $0.073(31)$ & & $0.044(31)$ \\
\hline $\operatorname{NHS}(=0 / 1)$ & $\begin{array}{l}\text { Standard. B } \\
\text { (p-value) }\end{array}$ & & $0.132(0.549)^{4}$ & & & & $-0.161(0.439)^{2}$ & & & \\
\hline \multirow[t]{2}{*}{$\mathrm{SHI}(=0 / 1)$} & $\begin{array}{l}\text { Standard. B } \\
\text { (p-value) }\end{array}$ & & $0.008(0.969)^{P}$ & & & & $-0.400^{*}(0.061)^{\$}$ & & & \\
\hline & $R^{2}(N)$ & & $0.016(31)$ & & & & $0.121(31)$ & & & \\
\hline \multirow[t]{2}{*}{$\begin{array}{l}\text { Government } \\
\text { responslbllity }\end{array}$} & $\begin{array}{l}\text { Standard. B } \\
\text { (p-value) }\end{array}$ & $-0.241(0.279)$ & $0.244(0.322)$ & $-0.229(0.502)$ & $-0.115(0.715)$ & $0.182(0.418)$ & $0.609^{\circ}(0.014)$ & $0.444(0.193)$ & $0.032(0.919)$ & $0.286(0.196)$ \\
\hline & $R^{2}(N)$ & $0.058(22)$ & $0.311(20)$ & $0.058(22)$ & $0.075(22)$ & $0.033(22)$ & $0.403(20)$ & $0.088(22)$ & $0.056(22)$ & $0.082(22)$ \\
\hline $\operatorname{TRANS}(=0 / 1)$ & $\begin{array}{l}\text { Standard. B } \\
\text { (p-value) }\end{array}$ & & & & $-0.182(0.563)$ & & & & $0.214(0.501)$ & \\
\hline $\begin{array}{l}\text { Chlldren caring } \\
\text { for Ill parents }\end{array}$ & $\begin{array}{l}\text { Standard. B } \\
\text { (p-value) }\end{array}$ & $-0.384^{\circ}(0.044)$ & $0.051(0.852)$ & $-0 . \pi 72(0.003)$ & $-0.406^{*}(0.081)$ & $-0.108(0.586)$ & $0.201(0.504)$ & $-0.381(0163)$ & $-0.374(0.103)$ & $-0.055(0.742)$ \\
\hline TRANS $(=0 / 1)$ & $\begin{array}{l}R^{2}(N) \\
\text { Standard. B } \\
\text { (p-value) }\end{array}$ & $0.147(28)$ & $0.243(26)$ & $0.309(28)$ & $\begin{array}{l}0.148(28) \\
0.039(0.864)\end{array}$ & $0.012(28)$ & $0.086(26)$ & $0.091(28)$ & $\begin{array}{c}0.165(28) \\
0.474^{\circ}(0.042)\end{array}$ & $0.004(28)$ \\
\hline $\begin{array}{l}\text { Healthy Impact } \\
\text { sclence/ } \\
\text { technology }\end{array}$ & $\begin{array}{l}\text { Standard. B } \\
\text { (p-value) }\end{array}$ & $0.016(0.930)$ & $-0.210(0.305)$ & $0.122(0.577)$ & $-0.051(0.830)$ & $-0.263(0.153)$ & $-0.453^{\circ}(0.024)$ & $-0.266(0.220)$ & $-0.169(0.462)$ & $-0.224(0.226)$ \\
\hline $\begin{array}{l}\text { technology } \\
\text { TRANS }(=0 / 1)\end{array}$ & $\begin{array}{l}R^{2}(N) \\
\text { Standard. B } \\
\text { (p-value) }\end{array}$ & $0.000(31)$ & $0.143(29)$ & $0.032(31)$ & $\begin{array}{c}0.008(31) \\
-0.112(0.641)\end{array}$ & $0.069(31)$ & $0.234(29)$ & $0.069(31)$ & $\begin{array}{l}0.084(31) \\
0.154(0.502)\end{array}$ & $0.050(31)$ \\
\hline
\end{tabular}

$* p<0.05 ; * p<0.1$

Multivariate Model I: Adjusted value for the involvement of GPS in first contact care for various health problems in 1993.

Multivariate Model II: Adjusted value for the GDP in PPP USD per capita in 1993.

Multiva riate Model III: Includes as independent variables healthea re system in transition (0/1) and each of the other listed independent variables.

Numbers in italic are $p$-values. Standardised $B$-values are bold when an association was termed significant, thus: if the $p$ value was $<0.05$ or $<0.1$.

2 Adjusted value for social health insurance system (0/1).

b Adjusted value for national health service system (0/1) 
Table 2. (Continued)

\begin{tabular}{|c|c|c|c|c|c|c|c|c|c|c|}
\hline \multicolumn{11}{|c|}{ PC system strength at process level by dimension } \\
\hline \multicolumn{3}{|l|}{ Continuity of PC } & \multicolumn{4}{|l|}{ Coordination of PC } & \multicolumn{4}{|c|}{ Comprehensiveness of PC } \\
\hline $\begin{array}{l}\text { Multiv. } \\
\text { model I }\end{array}$ & $\begin{array}{l}\text { Multiv. } \\
\text { model II }\end{array}$ & $\begin{array}{l}\text { Multiv. } \\
\text { model III }\end{array}$ & Simple madel & $\begin{array}{l}\text { Mult iv. } \\
\text { model I }\end{array}$ & $\begin{array}{l}\text { Multiv. } \\
\text { model II }\end{array}$ & $\begin{array}{l}\text { Multiv. } \\
\text { model III }\end{array}$ & Simple model & $\begin{array}{l}\text { Multiv. } \\
\text { model I }\end{array}$ & $\begin{array}{l}\text { Multiv. } \\
\text { model II }\end{array}$ & $\begin{array}{l}\text { Multiv. } \\
\text { model III }\end{array}$ \\
\hline & & $0.579^{\circ}(0.026)$ & $0.161(0.403)$ & & & $0.178(0.516)$ & $0.036(0.853)$ & & & $-0.104(0.706)$ \\
\hline & & $\begin{array}{c}0.203(29) \\
0.585^{\circ}(0.025)\end{array}$ & $0.026(29)$ & & & $\begin{array}{l}0.026(29) \\
0.025(0.928)\end{array}$ & $0.001(29)$ & & & $\begin{array}{c}0.02(29) \\
-0.199(0.470)\end{array}$ \\
\hline$-0.071(0.774)$ & & $0.397(0.137)$ & $0.077(0.679)$ & $-0.119(0.632)$ & & $-0.050(0.857)$ & $0.203(0.274)$ & $0.158(0.527)$ & & 0.111 (0.685) \\
\hline $0.032(29)$ & & $\begin{array}{c}0.118(31) \\
0.500^{-1}(0.064)\end{array}$ & $0.006(31)$ & $0.035(29)$ & & $\begin{array}{c}0.020(31) \\
-0.174(0.529)\end{array}$ & $0.041(31)$ & $0.017(29)$ & & $\begin{array}{c}0.049(31) \\
-0.126(0.049)\end{array}$ \\
\hline $0.372(0.139)$ & $0.352(0.189)$ & $-0.030(0.918)$ & $-0.155(0.406)$ & $0.019(0.941)$ & $-0.202(0.453)$ & $-0.119(0.688)$ & $-0.181(0.330)$ & $-0.028(0.911)$ & $-0.074(0.781)$ & $-0.053(0.856)$ \\
\hline $0.111(29)$ & $0.062(31)$ & $\begin{array}{l}0.045(31) \\
0.233(0.428)\end{array}$ & $0.024(31)$ & $0.026(29)$ & $0.026(31)$ & $\begin{array}{c}0.025(31) \\
-0.047(0.875)\end{array}$ & $0.033(31)$ & $0.002(29)$ & $0.044(31)$ & $\begin{array}{c}0.044(31) \\
-0.166(0.571)\end{array}$ \\
\hline $0.063(0.747)$ & $0.054(0.776)$ & $0.042(0.821)$ & $0.388^{\circ}(0.031)$ & $0.3399^{*}(0.074)$ & $0390^{\circ}(0033)$ & $0.396^{\circ}(0.029)$ & $0.190(0.307)$ & $0.089(0.552)$ & $0.195(0.291)$ & $0.201(0.276)$ \\
\hline $0.032(29)$ & $0.004(31)$ & $\begin{array}{l}0.046(31) \\
0.208(0.270)\end{array}$ & $0.150(31)$ & $0.140(29)$ & $0.158(31)$ & $\begin{array}{c}0.176(31) \\
-0.159(0.362)\end{array}$ & $0.036(31)$ & $0.009(29)$ & $0.079(31)$ & $\begin{array}{c}0.083(31) \\
-0.218(0.240)\end{array}$ \\
\hline$-0.024(0.918)$ & $0.041(0.835)$ & & $0.273(0.138)$ & $0.295(0.199)$ & $0.270(0.161)$ & & $0.112(0.548)$ & $0.129(0.585)$ & $0.067(0.729)$ & \\
\hline $\begin{array}{c}0.029(29) \\
-0.295(0.125)\end{array}$ & $\begin{array}{c}0.003(31) \\
-0.393^{*}(0.066)\end{array}$ & & $\begin{array}{c}0.074(31) \\
-0.160(0.390)\end{array}$ & $\begin{array}{c}0.087(29) \\
-0.245(0.207)\end{array}$ & $\begin{array}{c}0.075(31) \\
-0.267(0.218)\end{array}$ & & $\begin{array}{l}0.013(31) \\
0.095(0.612)\end{array}$ & $\begin{array}{l}0.013(29) \\
0.006(0978)\end{array}$ & $\begin{array}{c}0.045(31) \\
-0.010(0.962)\end{array}$ & \\
\hline $\begin{array}{c}0.114(29) \\
0.585^{\circ}(0.025)\end{array}$ & $\begin{array}{c}0.116(31) \\
0.500^{-1}(0.064)\end{array}$ & & $\begin{array}{c}0.026(31) \\
-0.138(0.459)\end{array}$ & $\begin{array}{l}0.085(29) \\
0.025(0.928)\end{array}$ & $\begin{array}{c}0.059(31) \\
-0.174(0.529)\end{array}$ & & $\begin{array}{c}0.009(31) \\
-0.207(0.264)\end{array}$ & $\begin{array}{c}0.001(29) \\
-0.199(0.470)\end{array}$ & $\begin{array}{c}0.041(31) \\
-0.126(0.6 .3)\end{array}$ & \\
\hline $\begin{array}{c}0.203(29) \\
-0.123(0.559)^{4}\end{array}$ & $0.118(31)$ & & $0.019(31)$ & $\begin{array}{l}0.026(29) \\
0.257(0.231)^{4}\end{array}$ & $0.020(31)$ & & $0.043(31)$ & $\begin{array}{l}0.022(29) \\
0.213(0.327)^{4}\end{array}$ & $0.049(31)$ & \\
\hline$-0.339(0.116)^{\mathrm{b}}$ & & & & $-0.031(0.883)^{p}$ & & & & $0.202(0.354)^{\mathrm{b}}$ & & \\
\hline $0.088(31)$ & & & & $0.075(31)$ & & & & $0.043(31)$ & & \\
\hline $0.400(0.158)$ & $0.741^{\circ}(0.023)$ & $0.223(0.476)$ & $-0.476^{\circ}(0.025)$ & $-0.366(0.182)$ & $-0.705^{\circ}(0027)$ & $-0.673^{\circ}(0.024)$ & $-0.438^{\circ}(0.041)$ & $-0.438(0.120)$ & $-0.665^{\circ}(0.0 .00)$ & $-0.555^{* *}(0.067)$ \\
\hline $0.117(20)$ & $0.246(22)$ & $\begin{array}{l}0.086(22) \\
0.090(0.771)\end{array}$ & $0.226(22)$ & $0.167(20)$ & $0.268(22)$ & $\begin{array}{l}0.267(22) \\
0.282(0.318)\end{array}$ & $0.192(22)$ & $0.137(20)$ & $0.233(22)$ & $\begin{array}{l}0.206(22) \\
0.166(0.567)\end{array}$ \\
\hline-0.002 (0.995) & $-0.189(0.500)$ & $-0.317(0.169)$ & $-0.414^{*}(0.028)$ & $-0.474(0.112)$ & $-0.612^{*}(0020)$ & $-0.457^{\circ}(0.048)$ & $-0.355^{*}(0.064)$ & $-0.670^{*}(0.024)$ & $-0.483^{*}(0.072)$ & $-0.379(0.105)$ \\
\hline $0.017(26)$ & $0.021(28)$ & $\begin{array}{c}0.143(28) \\
0.449^{-1}(0.055)\end{array}$ & $0.171(28)$ & $0.147(26)$ & $0.213(28)$ & $\begin{array}{l}0.175(28) \\
0.076(0.731)\end{array}$ & $0.126(28)$ & $0.203(26)$ & $0.143(28)$ & $\begin{array}{l}0.127(28) \\
0.043(0.849)\end{array}$ \\
\hline$-0.327(0.121)$ & $-0.325(0.135)$ & $-0.152(0.514)$ & $0.241(0.192)$ & $0.153(0.477)$ & $0.272(0.212)$ & $0.248(0.291)$ & $\mathbf{0 . 4 3 3}^{\circ}(0.015)$ & $0.455^{\circ}(0030)$ & $0.446^{\circ}(0.032)$ & $0.487^{\circ}(0.030)$ \\
\hline $0.116(29)$ & $0.079(31)$ & $\begin{array}{l}0.059(31) \\
0.118(0.613)\end{array}$ & $0.058(31)$ & $0.045(29)$ & $0.061(31)$ & $\begin{array}{l}0.058(31) \\
0.012(0.958)\end{array}$ & $0.188(31)$ & $0.171(29)$ & $0.188(31)$ & $\begin{array}{l}0.193(31) \\
0.088(0.684)\end{array}$ \\
\hline
\end{tabular}




\section{Appendix 1 - Correlation matrix}

Pearson correlation matrix of dependent and independent variables

\begin{tabular}{|c|c|c|c|c|c|c|c|c|c|c|c|c|c|c|}
\hline & $\begin{array}{l}\text { Access } \\
\text { of PC }\end{array}$ & $\begin{array}{l}\text { Continuity } \\
\text { of PC }\end{array}$ & $\begin{array}{l}\text { Coordination } \\
\text { of PC }\end{array}$ & $\begin{array}{l}\text { PC Compre- } \\
\text { hensiveness }\end{array}$ & $\begin{array}{c}\text { First contact } \\
\text { care } 1993\end{array}$ & $\begin{array}{l}\text { GDP per } \\
\text { capita }\end{array}$ & $\begin{array}{l}\text { Growth in } \\
\text { GDP }\end{array}$ & $\begin{array}{l}\text { Government } \\
\text { composition }\end{array}$ & $\begin{array}{l}\text { NHS } \\
\text { system }\end{array}$ & $\begin{array}{l}\text { SHI } \\
\text { system }\end{array}$ & $\begin{array}{l}\text { TRANS } \\
\text { system }\end{array}$ & $\begin{array}{l}\text { Government } \\
\text { action }\end{array}$ & $\begin{array}{l}\text { Family } \\
\text { orientation }\end{array}$ & $\begin{array}{l}\text { Science \& } \\
\text { technology }\end{array}$ \\
\hline PC structure strength & $0.49^{* *}$ & -0.01 & $0.43^{*}$ & 0.26 & 0.33 & -0.14 & -0.05 & $0.48^{* *}$ & 0.13 & -0.06 & -0.08 & -0.24 & $-0.38^{*}$ & 0.02 \\
\hline Access (PC process strength) & & 0.28 & 0.27 & -0.00 & 0.26 & -0.13 & -0.06 & 0.33 & 0.04 & -0.32 & 0.26 & 0.18 & -0.11 & -0.26 \\
\hline Continuity (PC process strength) & & & -0.18 & 0.13 & 0.17 & 0.03 & 0.15 & -0.04 & 0.05 & -0.28 & 0.21 & 0.29 & -0.07 & -0.22 \\
\hline Coordination (PC process strength) & & & & 0.23 & 0.16 & 0.08 & -0.16 & $0.38^{*}$ & 0.27 & -0.16 & -0.14 & $-0.48^{*}$ & $-0.41^{*}$ & 0.24 \\
\hline $\begin{array}{l}\text { Comprehensiveness (PC process } \\
\text { strength) }\end{array}$ & & & & & 0.04 & 0.20 & -0.18 & 0.19 & 0.11 & 0.10 & -0.21 & $-0.44^{*}$ & -0.36 & $0.43^{*}$ \\
\hline $\begin{array}{l}\text { GPs' involvement first contact care } \\
1993\end{array}$ & & & & & & $0.62^{* *}$ & $-0.64^{* *}$ & 0.01 & $0.55^{* *}$ & 0.12 & $-0.70^{* *}$ & $-0.54^{*}$ & $-0.74^{* *}$ & $0.43^{*}$ \\
\hline GDP per capita & & & & & & & $-0.71^{* *}$ & -0.07 & 0.24 & $0.51^{* *}$ & $-0.73^{* *}$ & $-0.75^{* *}$ & $-0.70^{* *}$ & $0.51^{* *}$ \\
\hline \% Growth in GDP per capita & & & & & & & & -0.03 & $-0.40^{*}$ & $-0.38 *$ & $0.77^{* *}$ & $0.63^{* *}$ & $0.62^{* *}$ & -0.34 \\
\hline $\begin{array}{l}\text { Yrs left party government } \\
\text { dominance }\end{array}$ & & & & & & & & & 0.12 & -0.19 & 0.05 & -0.32 & -0.06 & -0.05 \\
\hline NHS system & & & & & & & & & & $-0.50^{* *}$ & $-0.59^{* *}$ & -0.42 & -0.31 & $0.38^{*}$ \\
\hline SHI system & & & & & & & & & & & $-0.41^{*}$ & -0.36 & -0.27 & 0.22 \\
\hline Transition system & & & & & & & & & & & & $0.70^{* *}$ & $0.56^{* *}$ & $-0.61^{* *}$ \\
\hline $\begin{array}{l}\text { \% pop. agree government should } \\
\text { take more responsibility provide } \\
\text { welfare }\end{array}$ & & & & & & & & & & & & & $0.70^{* *}$ & $-0.68^{* *}$ \\
\hline $\begin{array}{l}\text { \% pop. prefers children take care of } \\
\text { diseased parents }\end{array}$ & & & & & & & & & & & & & & $-0.58^{* *}$ \\
\hline
\end{tabular}

${ }^{* *}$ Statistically significant at $\alpha<0.01$

* Statistically significant at $\alpha<0.05$ 